DOI 10.14746/ssp.2014.2.1

Marian BRODA

Uniwersytet Łódzki

\title{
Rosja - autorytaryzm - demokracja - między iluzją i realnością
}

$D_{\text {go państwa, ładu ustrojowego, mechanizmów rozwojowych i życia }}^{\text {iagnozy i prognozy, dotyczace Rosji w ogóle, a charakteru tamtejsze- }}$ polityczno-społecznego, w jego aktualnej czy spodziewanej, przyszłej formie, w szczególności, odznaczają się zastanawiająco często wyraźnie spotęgowaną, periodycznie nasilającą się, dychotomiczną wręcz niekiedy, polaryzacja, przeciwstawnością i zmiennością. Analizując procesy transformacji rosyjskiego systemu społeczno-politycznego, a także podejmowane próby rozpoznania charakteru, celów, kierunku i spodziewanych konsekwencji obserwowanych przemian, warto zatem pamiętać o kilku podstawowych problemach identyfikacyjnych, jakie im nieprzypadkowo towarzyszą. Ich przesłanek i objaśnień, można i należy szukać zarówno po stronie przedmiotowej (właściwości rzeczywistości rosyjskiej), jak i po stronie podmiotowej (sposoby jej percepcji, konceptualizacji i problematyzacji), na której skoncentrowane będą przede wszystkim poniższe uwagi; przy czym obie one pozostają ze sobą powiązane, współokreślając się wzajemnie.

W wyrosłych na prawosławnej glebie mentalności i kulturze rosyjskiej, zdominowanych przez silny ładunek eschatologiczny i korelujące z nim poszukiwanie docelowego - paruzyjnego czy quasi-paruzyjnego - wspólnotowego Spełnienia, za szczególnie ważny uważany jest wymiar przyszłości (Špidlik, 2000, s. 431 i in.). Co więcej, bardzo często przypisuje mu się również faktyczną nadrealność i niezależność w stosunku do empirycznie uchwytnej historii i teraźniejszości. Przyszłość pojmuje się jednocześnie w kategoriach próby inicjacyjnej, której Rosja może - albo nie - sprostać, dychotomizując każdorazowo wizje i oceny tego, co zaczyna się dokonywać. Podmiotową siłę, tworzącą historię, utożsamia się tam tradycyjnie właśnie $\mathrm{z}$ - aktualną lub potencjalną - centralną władzą państwową. W jej istnieniu, potędze i działaniu widzi się nie tylko gwarancję, ale również podstawę i kreatora porządku społecznego, a zarazem nosiciela ponadpartykularnej racji i prawdy (Špidlik, 2000, s. 3). Jeśli aktualna 
władza traci podobne przymioty i zdolności, staje się, w oczach Rosjan, narzędziem równie hipertroficznie pojmowanego rozkładu i nosicielem antyprawdy. Traci ona wówczas swą legitymizację i, jak oczekuje się, powinna zostać zastąpiona przez inną (Domnikow, 2003, s. 225, 250, 372-274), przeżywaną i pojmowaną w podobny, jak wcześniej poprzednia, sposób.

Rodzaj i skala oczekiwań Rosjan wobec personifikowanej przez nich od stuleci samodzierżawnej władzy mają charakter szczególny: rządzenie, przewodzenie, moc, ład, tożsamość, prawo, prawda i słuszność wiążą się tam integralnie ze soba, a rzeczywistą legitymizację zyskuja jedynie władza, zdolna sprostać podobnej totalności oczekiwań. W rosyjskiej świadomości i tradycji politycznej władza pozostaje nosicielem i narzędziem wyższej - religijnej bądź ideologicznej - Prawdy, nadającej jej szczególny status i uprawnienia. Nie chodzi tu jedynie o uzurpatorskie ambicje samej władzy, ale również o głęboko utrwalone i szeroko rozpowszechnione przeświadczenia, oczekiwania i potrzeby wielu grup i środowisk społeczeństwa rosyjskiego. Nie przypadkiem wybór osoby następnego przywódcy większość Rosjan pozostawia faktycznie aktualnemu władcy (któż, jak nie on, może wiedzieć, co jest dla Rosji najlepsze?). W czasach współczesnych odmówienie przez takiego nominata swego udziału $\mathrm{w}$ dyskusjach z formalnie równorzędnie traktowanymi innymi kandydatami nie podważa bynajmniej jego szans wyborczych, ani nie zmniejsza społecznego dlań poparcia. Zdolność wyniesienia się czy pozostawanie wyniesionym ponad równoprawny, pluralistyczny dialog z innymi siłami politycznymi odbierane są bowiem jako szczególna legitymizacja uprawnienia do sprawowania władzy.

W rosyjskiej tradycji władcy i władzy przypisuje się szczególny status „prawa upostaciowanego". Wiele z ustaw - nie mówiąc już o zapowiedziach ich uchwalenia - nie formułuje się tam z zamiarem rzeczywistego wprowadzenia (zwłaszcza w rozumieniu zachodnim) w życie: pozostaja one „czystym aktem ideologicznym, rytualnym gestem Panującego" (Truscott, 2004, s. 350), kreowaniem rzeczywistości, w którą Rosjanie winni wierzyć, a nie empirycznie ją sprawdzać czy prawnie egzekwować. Fakt, że władza w Rosji znajduje się wciąż zasadniczo ponad prawem i jej samodzierżawne aspiracje nie napotykają skutecznego sprzeciwu, a znacznie częściej zrozumienie i poparcie większości społeczeństwa, nie oznacza jednak wcale nieograniczonych możliwości modernizacyjno-rozwojowych kraju czy absolutnej swobody jej działań. Społeczne uprawomocnienie władzy, oparte o pierwiastek autorytarny i zdolność przejawiania 
mocy oraz groźba destrukcyjnych następstw sytuacji, gdy owej zdolności zabraknie, wzmacniają tendencje do zachowania tradycyjnego charakteru relacji między centrum politycznym i społeczeństwem oraz tradycyjnego ładu społecznego w ogóle. W istniejących warunkach w sferze aktywności władzy w sposób naturalny nie mieszczą się działania, zmierzające do wprowadzenia w Rosji rzeczywistego trójpodziału władzy, uznania prawdziwej niezawisłości sądów i wolności środków masowej informacji, rządów prawa jednakowo obowiązującego wszystkich, politycznego pluralizmu, społeczeństwa obywatelskiego, uwolnienia gospodarki od dyktatu polityki itp. Jedynie pozostawanie w sferze tradycyjnego, rosyjskiego czy szerzej archaicznego, mitu, który, przypisując najwyższej władzy quasi-boską naturę, uwalnia ją z uwikłania w sferę partykularnych -w szczególności własnych - interesów (Billington, 2005, s. 120) i mechanizmów funkcjonowania istniejącego systemu polityczno-społecznego, pozwala myśleć o sprawie inaczej.

W świadomości wielu Rosjan parlament, niezależne od władzy media, partie polityczne i organizacje społeczne są nie tyle instytucjonalną gwarancją praw i swobód obywatelskich, co instrumentem walki partykularnych interesów oligarchów i polityków. Władza kremlowska i podporządkowane jej media konsekwentnie ugruntowują podobny sposób myślenia, zakorzeniony głęboko w mentalności rosyjskiej, dla której artykułowane roszczenia jednostek i grup, dotyczące wyznaczenia sfery ich wolności, rzeczywiście ograniczającej możliwość ingerencji państwa, odbierane są jako zamiary i działania antywspólnotowe i antyspołeczne, sterowane z zewnątrz i służące wrogom Rosji. W ograniczaniu swobody działania, a nawet w likwidowaniu, rozmaitych instytucji społeczeństwa obywatelskiego i instrumentalnym włączaniu ich w kremlowski system rządzenia, miliony mieszkańców kraju widzą przede wszystkim nie atak na sferę wolności obywatelskich i podstawowe zasady demokracji, lecz walkę z nadużyciami.

Silne rządy przywracają - jak dotąd, każdorazowo - sytuację w Rosji normalną: gdy zlokalizowana w centrum władza państwowa okazuje się zdolna do przejawienia swej mocy, pozostałe siły polityczne ulegają radykalnej marginalizacji, a skuteczna opozycja przestaje istnieć (Timczenko, 2005, s. 108-109). Jeśli nie zostaje ona zlikwidowana przez władzę, traci - do czasu kolejnej smuty - swe politycznie liczące się społeczne podstawy i wpływy. Opozycja zaczyna być wówczas przejmowana i kontrolowana, a czasem wręcz powoływana i kierowana, przez władze kremlowskie (Sakwa, 2002, s. 95-97). Znaczna część opinii publicznej zaczyna widzieć 
w niej po prostu intrygę władzy, stwarzanie pozorów czy drwinę z demokracji, albo też kolejne wcielenia antypaństwowego zła, szkodzącego narodowej wspólnocie. Demonstrowana brutalność w stosunku do niepokornych wobec niej przejawów i sił opozycji, w oczach wielu Rosjan nie przynosi uszczerbku na społecznym wizerunku władzy (Kenez, 2008, s. 348), stając się niejednokrotnie środkiem mobilizacji wyborczego poparcia dla rządzących, a nawet swego rodzaju świadectwem i demonstracją prawomocności istniejącej władzy. Podobnie, tworzenie przez nią partii politycznych czy organizacji „obrony praw człowieka” nie odejmuje owym formom społecznej wiarygodności; przeciwnie, czasem wręcz jej przydaje.

Rosyjski obraz władzy sięga swymi korzeniami hierarchii rodowej, wiążąc się z takimi wyobrażeniami świata, w których społeczne, polityczne i religijno-magiczne aspekty hierarchii łączą się ze sobą w jedną całość. Niczym ucieleśnienie pogańskiego Boga: „Władza jest nosicielem prawdy, władczynią wszystkiego, co istnieje, źródłem innowacji, źródłem praw stojącym ponad prawem [...]; monopolizuje społeczną podmiotowość, od swych poddanych może wymagać ofiar, postrzegana jest jako nieprzenikniona i wszechobecna. Sakralnej Władzy ontologicznie przeciwstawiony jest profaniczny poddany" (Jakowienko, 2008, s. 42-43; Siergijewa, 2006, s. 165), traktowany w sposób instrumentalny i przedmiotowy. W sferze mentalności rosyjskiej pozostaje ona od wieków kategorią sakralna, mistyczno-kosmologiczną, uważaną de facto za samowystarczalną, stanowiącą praprzyczynę wszelkiego porządku, również samej siebie (Pielipienko, brak daty, s. 5). Jako taka sytuowana jest ona poza sferą ,immanentnych społeczeństwu instytucji, stosunków i tradycji”" (Pielipienko, brak daty, s. 5), w szczególności ponad prawem; podlegając ziemskim prawom czy profanicznym kategoriom „,rozsądku” ujawniałaby zatem nie tylko swą słabość, ale i nieautentyczność: „Wola Władzy, niczym antyczne fatum lub wola chrześcijańskiego Boga, jest nieprzewidywalna i niepojmowalna" (Pielipienko, brak daty, s. 6).

Pole znaczeniowe rosyjskiego słowa ,władza” jest od wieków bardzo szerokie: „To i «panować», i «rządzić», i «przymuszać», i «wpływać» itd. Nawet więcej jest ono związane z pierwotną symbolizacją początków życia, stanowieniem porządku itp. Nosiciel i przedstawiciel władzy to «naczelnik» [ros. naczalnik od naczało tj. początek, ale również zasada i prawo - przyp. M.B.], będący postacią związaną ze społecznym początkiem" (Kantor, 1991, s. 13) - ten, kto wprowadza ład, formułuje prawo, daje sobie radę, postępuje zgodnie z prawdą (Kantor, 1991, s. 13). 
Również - karmi i żywi: „,inne określenie władcy - «ten, który karmi» (od słowa kormit'; aparat władzy - kormiło) - wyraźnie wskazuje na semantykę dość wczesnego pochodzenia" (Kantor, 1991, s. 13). Znaczeniowe konteksty rosyjskiego słowa kormiło łączą owo „karmienie” i ,żywienie” ze staniem u steru i trzymaniem tego steru (jednego z symboli sprawowania władzy). Staroruskie mądrości i przysłowia wiążą z władzą - a bezpośrednio z jej najwyższą ziemską personifikacją - treści sakralne i boskie, władzę, prawo i prawdę: ,Jeden jest Bóg i jeden car”, „Bez Boga świat nie istnieje, a bez cara nie jest rządzony”, „Karać i darować karę [wolno - przyp. M.B.] Bogu i Carowi”, „Wie Bóg i car”, „Gdzie Car, tam i prawda" (Billington, 2005, s. 120).

W mentalności i kulturze rosyjskiej, ukształtowanej zarówno pod wpływem prawosławia - zachowującego relatywnie więcej niż chrześcijaństwo zachodnie treści typowych dla archaicznej percepcji świata, ontologizującej przeciwstawność Prawdy i Krzywdy (Achijezier i in., 2002, s. 386-387) oraz silniej absolutyzującego kontrast między dobrem a złem (Meyendorff, 1984, s. 211, 281-284; Teichgraber, 1999, s. 41-42) - jak i realiów polityczno-społecznych kraju, w którym przez wieki brakowało miejsca na postawy pośrednie między serwilizmem a buntem, między pełną identyfikacją z istniejącym porządkiem państwowym a jego totalną negacją, w sposób całkowicie naturalny brakowało miejsca na sferę aksjologicznie neutralną. Spotęgowana dychotomizacja wartości i antywartości, wykluczała pryncypialnie istnienie zachowań i instytucji, które nie musiałyby być „,boskie” albo „,szatańskie”, „święte” albo „grzeszne”, „państwowe” albo „,antypaństwowe”, ,postępowe” albo „wsteczne”, „demokratyczne” albo ,antydemokratyczne” itd. (Jakowienko, 2008, s. 42).

W kraju o wielowiekowej tradycji personifikacji samodzierżawnej władzy identyfikacyjne zabiegi, dotyczące charakteru politycznej rzeczywistości Rosji, w sposób naturalny ogniskują się na osobie władcy czy przywódcy państwa. Skala i zasięg spodziewanego, lub już dostrzeganego, wpływu personifikowanych zmian politycznych na losy kraju, wykraczają zwykle daleko poza ich odpowiedniki, pojawiające się w przypadku podobnych sytuacji we współczesnych społeczeństwach zachodnich. W ramach rozpatrywanego sposobu pojmowania świata, w odniesieniu do celów i rezultatów działań jednego i tego samego rosyjskiego przywódcy, i jego ekipy, mogą zatem pojawić się tak spolaryzowane wzajemnie diagnozy, identyfikacje i towarzyszące im oceny, jak: konsolidująca i destrukcyjna, rozwojowa i regresywna czy zastojowa, autorytarna i demokratyczna, europejska i antyeuropejska czy azjatycka itd. 
W roli symtomatycznego świadectwa i konkretyzacji powyższego można posłużyć się przypadkiem Władimira Putina. Formuły identyfikacyjne, odnoszone do niego po objęciu przezeń władzy, były tyleż liczne, co zadziwiająco wręcz zróżnicowane - od określeń: „Niemiec na Kremlu”, ,rosyjski de Gaulle”, „Putinochet”, „Europejczyk”, „okcydentalista”, „antyokcydentalista”, „,czekista”, „humanistyczny liberał” „,bolszewik”, „pozytywista”, „bezlitosny dyktator typu Stalina”, „reformator z KGB”, ,autokrata z przypadku”, „,niewattpliwy demokrata”, „car Władimir Rockefellerowicz”, ,raczej konserwatysta niż demokrata, zwolennik surowej władzy”, „Gazputin”, „Władimir I Groźny”, „Borys II Putin”, „Władimir III”, „Kim Il Putin”, „,mały car”, ,nowy Piotr Wielki”, po pytania: ,,polityk czy urzędnik?”, „demokrata czy tylko reformator?”, „okcydentalista czy słowianofil?”, ,car czy doża?”, ,zwolennik wtłoczenia Rosji w «cywilizację światową» czy stronnik «szczególnej drogi rosyjskiej»?”, „Kim jest Putin?” lub w bardziej okcydentalistycznej stylizacji: „Kim Pan jest, mister Putin?".

Powtarzające się cyklicznie w historii Rosji okresy głębokiego kryzysu, określanego mianem smuty rodzą tęsknotę za inwersją, przemienieniem zaistniałych stanów i dokonujących się procesów w ich radykalne przeciwieństwo: amorficzności w określoność, rozkładu w rozwój, bezsilności w potęgę... Okresy smuty przeżywane są jednocześnie, paradoksalnie, jako zapowiedź, a nawet swoista rękojmia, przyszłego spełnienia. Moment spodziewanej, pozytywnej inwersji odnoszony jest tam bowiem do sytuacji szczytowego nasilenia destrukcji, upadku i sprzeczności (Kondakow, 2006, s. 111-116; Cirlot, 2000, s. 164-165). W ramach podobnej percepcji świata realne i bliskie staje się to, co w kategoriach empirycznych wydawać się mogłoby właśnie nierealne, a przynajmniej bardzo wątpliwe i odległe w czasie: rzeczywiste, na zachodni sposób rozumiane, rządy prawa, stanie się kulturowym wzorem dla Zachodu, rozwojowe, technologiczno-ekonomiczne prześcignięcie wszystkich innych państw, ale i rekomunizacja czy resowietyzacja, imperialna dominacja w świecie, wskazanie światu drogi w „trzeciorzymową” przyszłość itp.

W porównaniu $\mathrm{z}$ - porenesansowym zwłaszcza - Zachodem w myśleniu rosyjskim silniej zachowywane są pierwiastki kosmizmu i religijnej immanencji, leżące u podstaw wspólnotowej ufności w realność zasadniczej przemiany świata (prawosławna idea „przebóstwienia” świata oraz jej rozmaite ideologiczne surogaty i odpowiedniki) (Eliade, 1995, s. 42; Meyendorff, 1984, s. 43 i in.; Iljn, 2007, s. 96). Relatywnie słabiej akcentowana jest natomiast historyczność zjawisk i procesów oraz świadomość 
dziejowego do nich dystansu. Sprzyja to tendencji do pojmowania historii jako swoistej księgi archetypicznych powtórzeń określonych sytuacji i zachowań (Klinger, 1983, s. 163), w następstwie czego, czasowa i kulturowa odległość pomiędzy okresami rządów poszczególnych władców czy form ustrojowych występujących w Rosji przestaje być zasadniczą przeszkodą dla najrozmaitszych porównawczych „współujęć”, identyfikacji, objaśnień i przewidywań. Mówią one zatem wiele nie tylko o aktualnej rzeczywistości polityczno-społecznej Rosji, ale przede wszystkim o historycznie utrwalonych i kultywowanych we wspólnotowej tradycji sposobach jej konceptualizacji, o sprawach związanych ze źródłami, uwarunkowaniami i charakterem sposobu postrzegania przez Rosjan świata, społeczeństwa i władzy.

W mentalności i kulturze rosyjskiej występuje wyraźna skłonność do dzielenia czasu w ogóle, a historii kraju w szczególności, na okresy czy etapy, zdolne stanowić jakoby - przynajmniej potencjalnie - pełne zerwanie z przeszłością. W szczególności zmiana władcy czy zapowiadające przemiany proklamacje władzy wydają się w oczach wielu Rosjan potencjalnie znamionować nową epokę, określaną przez osobowość władcy czy charakter władcy, wynoszone de facto, również w wymiarze swego wpływu politycznego, ponad podstawowe determinacje historyczne i podporządkowujące je sobie. Moment nieciagłości, oddzielający teraźniejszość od Przyszłości, czekającej jakby na swe spełnienie, nabiera wówczas charakteru przeszkody, którą trzeba - i można - pokonać nadludzkim de facto czynem władczej woli (Faryno, 1995, s. 12-13). Rozpowszechnione jest również przeświadczenie o przysługującym jakoby Rosji przywileju szczególnej wolności. Zgodnie z nim jej losy i przemiany się tam dokonujące nie podlegają, a przynajmniej nie muszą podlegać, podstawowym ograniczeniom, determinacjom i uwarunkowaniom, którym poddane są $\mathrm{w}$ innych krajach (Broda, 1995, 23-42). W następstwie dramatycznych często rezultatów prób historycznej weryfikacji podobnej wiary, nie obywa się bez pewnej istotnej ambiwalencji. Biegunowym odpowiednikiem ufności, że w Rosji „wszystko jest możliwe”, otwierającej niemal bezkresną przestrzeń możliwych prognoz i identyfikacji staje się równie krańcowo pojmowany fatalizm, w myśl którego jakakolwiek zasadnicza zmiana przestaje być tam wówczas możliwa - poza następowaniem po sobie kolejnych faz cyklu: autorytaryzm-smuta-autorytaryzm..., sprowadzającym zabiegi identyfikacyjne do kwestii określenia aktualnie dokonującej się „fazy”.

W kwestii rozpoznawanego, autokratycznego czy demokratycznego, charakteru politycznych pokomunistycznej Rosji, a w szczególności ob- 
serwowalnej tendencji do wzajemnej dychotomizacji formułowanych diagnoz istotną rolę odgrywała - zwłaszcza w okresie pierwszego piętnastolecia po upadku ZSRR - sprawa uwikłania w sowiecką przeszłość. Jednym z jej przejawów, fatalizującym wpływ komunistycznego dziedzictwa na rosyjską rzeczywistość była skłonność do absolutyzowania siły i trwałości związków osoby i ekipy Putina z komunistyczną Rosją, jej ideologią i siłami bezpieczeństwa, sprzyjająca jednostronnemu wiązaniu sowietyzmu i Putinowskiej Rosji, mechanicznemu wręcz niekiedy identyfikowaniu i kwalifikowaniu obserwowanych zjawisk i procesów jako symptomów resowietyzacji; drugim natomiast - skoro ZSRR przestał istnieć - ufność w możliwość łatwego, szybkiego i pełnego uwolnienia się Rosji i Rosjan spod owego wpływu.

Analizy różnorakich uwarunkowań podatności Rosji i Rosjan XX wieku na procesy bolszewizacji pozwalają bez wątpienia ujawnić cały szereg sprzyjających temu czynników, głęboko wpisanych w najszerzej rozumianą tradycję polityczno-kulturową oraz rzeczywistość instytucjonalną i społeczno-mentalną kraju. Wiele z nich - mimo rozmaitych zmian, modyfikacji i metamorfoz - pozostaje żywotnymi również dziś, wpływając na postawy, ambicje, dążenia i zachowania Rosjan i władz rosyjskich, w szczególności prezydenta Putina i jego współpracowników. Wcale niekoniecznie, i wraz z upływem lat w coraz mniejszym stopniu, są one jednak po prostu kontynuacją swych bolszewickich i sowieckich odpowiedników, czy bezpośrednią pochodną komunistycznego elementu biografii nowych władców Rosji. Ich żywotności sprzyjają bowiem również treści o naturze znacznie ogólniejszej i bardziej trwałej, z dziedziczeniem określonego charakteru relacji między władzą a społeczeństwem, grupą i jednostką, sposobu pojmowania własnej tożsamości oraz typu reakcji na - przede wszystkim zachodni - kontekst zewnętrzny oraz związane z tym wyzwania cywilizacyjne, towarzyszące losom Rosji od kilku przynajmniej stuleci (Broda, 2009a, s. 14-29, 44-50, 53-66, 86-93 i in.).

Od czasów Piotra I stałym punktem - pozytywnego, negatywnego, ambiwalentnego itp. - odniesienia dla świadomości rosyjskiej pozostaje Europa i Zachód, a także związane z tym kulturowe, społeczne i polityczne kategorie identyfikacyjne (Broda, 2011, s. 292-293, 328-332). Rodzimą rzeczywistość ujmuje się i ocenia przez pryzmat kategorii zachodnich albo, przeciwnie, stara się pokazać i uzasadnić ich zasadniczą niestosowalność do Rosji. W pierwszym przypadku pojawia się tendencja do poszukiwania zachodnich analogii dla identyfikacji i objaśnienia rosyjskich realiów i sytuacji, wskazywania symptomów pozytywnie ocenianego kie- 
runku społecznej ewolucji własnego kraju itd. W drugim natomiast identyfikacyjne i objaśniające analogie poszukiwane są w historii samej Rosji, a dostrzegane i akcentowane przejawy odmienności od Zachodu są absolutyzowane i jednostronnie dodatnio wartościowane. $\mathrm{W}$ okresie popiotrowym lejtmotywem rosyjskiej świadomości potocznej oraz tradycji intelektualnej i ideologicznej staje się, w rozmaity sposób artykułowane i konceptualizowane, poczucie „braku tożsamości”, bycia „między”, w „pęknięciu”, w „szczelinie”. Potęguje ono ciążenie myśli rosyjskiej ku skrajności, ambiwalencji, radykalności i rewolucyjności (Dobieszewski, 1986, s. 31-38), stymuluje poszukiwanie - traktowanej jako realna i zasadna - drogi ,na skróty" ku pełnej europeizacji, demokratyzacji czy liberalizacji Rosji albo też ku jej nieeuropejskiemu właśnie, swoiście rosyjskiemu, samodzierżawnemu spełnieniu. Dodatkowemu wzmocnieniu ulega wówczas oczekiwanie i poszukiwania rozwiązań definitywnych i wiara w ich realność.

W ramach dychotomicznych schematów identyfikacyjnych, ujednostranniających obraz objaśnianej rzeczywistości społeczno-politycznej, wyrywane z wzajemnego, pre-epistemicznego związku i szerszego kontekstu, działania, stany i procesy zyskują siłą rzeczy - dekretowany de facto w znacznym stopniu - binarny, ambiwalentny bądź paradoksalny charakter. W następstwie powyższego, równie radykalnie „pasują” one albo, przeciwnie, „nie pasują" wówczas do określonych matryc eksplanacyjnych, w które są wpisywane: rodzimych i zachodnich, swoiście rosyjskich i uniwersalnych, modernizacyjnych i antymodernizacyjnych, demokratycznych i antydemokratycznych, progresywnych i regresywnych itp. $\mathrm{Na}$ myśleniu o Rosji ciąży ponadto niejednokrotnie, dychotomizujący wizje przyszłości kraju, mit jakoby jej naturalnym przeznaczeniem była europejskość w ogóle, a zachodnia demokracja i obywatelskość w szczególności, które - w przeżywanym właśnie okresie - może się dopełnić, chyba, że wybierze ona swą, zupełnie jakoby nieeuropejską, „rosyjskość”, wyzbywając się, z kolei, całkowicie i finalnie ze swojego oblicza wszelkich europejskich treści, idei i form, obywatelskich i wolnościowych. W podobnie binarnym kontekście interpretowane są często rozmaite konkretne decyzje rosyjskiej władzy. Należy pamiętać, że nowożytne oblicze Rosji, jej dynamikę i kolejne metamorfozy samoświadomości społecznej-określa, generująca określone tendencje i kontrtendencje rozwojowe, współobecność i wzajemna interakcja pierwiastków rodzimych i zachodnich, tworząc nieredukowalną już do nich rzeczywistość kulturowa, społeczną i polityczną.

Uświęcone tradycją, społeczne, polityczne i kulturowe ambicje wielu Rosjan nie przypadkiem wyznaczone są w znacznym stopniu przez finali- 
stycznie pojmowaną ideę „pozytywnej syntezy” wartości rodzimych i zachodnich. Koresponduje z tym m.in. pojawianie się rozmaitych hybryd ideologicznych, takich jak: „dyktatura prawa”, „suwerenna demokracja”, „suwerenna cywilizacja” czy „demokracja sterowana”. Doświadczenia historyczne zdają się jednak stawiać przed Rosjanami raczej problem możliwości uniknięcia realności syntezy negatywnej: powstania karykaturalnej „Azjopy” zamiast oczekiwanej „Euroazji” (Kara-Murza, 1998, s. 7), a więc, dla przykładu, w rozpatrywanej sferze rosyjskiej rzeczywistości, demokratury zamiast demokracji. W momencie, czy w przeczuciu, podobnego rozczarowania reakcją obronną staje się zwykle autoperswazyjne podkreślanie rosyjskiej odmienności, osłabiające potrzebę uczestniczenia w wartościach zachodnich oraz napięcia związane ze świadomością ograniczoności owej partycypacji. Gdy z czasem, dystansująca się od europejskich wzorców opcja przynosi również zawód, odżywają ponownie prozachodnie sympatie itd. Rosjanie tak naprawdę nie są wciąż - nie bardzo mogą być - pewni i nie mogą zdecydować, czy ich kraj ma być częścią Europy czy jej alternatywą (Broda, 2002, s. 10-14, 18-22). Usiłując wyjść z sytuacji przeżywanej jako brak tożsamości, dwoistość czy wewnętrzne rozdarcie, jednocześnie odtwarzają wciąż stan istniejący i dekretują jego „przejściowość”.

Podstawowym rysem rosyjskiej rzeczywistości ostatnich stuleci wydają się być, ulegające reprodukcji - nie bez periodycznych kryzysów i specyfikacji - struktura, mentalność i tradycja autorytarno-imperialna, wytwarzające swe, systemowo uwarunkowane, świadomościowe i instytucjonalne, mentalne, polityczne, społeczne, kulturowe, moralne i ideologiczne, obiektywizacje i odpowiedniki (Afanasjew, 2009, s. 12-16). Obserwowane w ostatnich latach ponowne próby wkraczania przez Rosję na drogę, zmierzającą do odbudowy tamtejszej tradycji mocarstwowo-imperialnej, większości jej mieszkańców wydaje się wciąż czymś prostszym i bardziej naturalnym, czy wręcz samozrozumiałym, niż próby dokonania gruntownych przewartościowań owej tradycji, które musiałyby bowiem dotyczyć samych podstaw rosyjskiej tożsamości i związanego z nimi typu ładu społecznego, struktur mentalnych, narodowych ambicji i kulturowych wzorów.

Jest wysoce watpliwe, by zasadniczo inny od realizowanego od początku XXI w. program polityczno-ideologiczny i gospodarczy (w szczególności liberalny w stylu zachodnim) mógł stać się w przewidywalnym horyzoncie czasowym w Rosji alternatywną podstawą konsolidacji i przebudowy społecznej. Podtrzymywanie niektórych istotnych treści rosyj- 
skiej tradycji politycznej i związanego z nimi typu ładu społecznego stanowiło - i wciąż wydaje się tam stanowić - niezbędny warunek możliwości powstrzymywania procesów dezintegracji i rozkładu, a więc i, we wskazanym elementarnym przynajmniej sensie, przesłankę jakiejkolwiek modernizacji rozwojowej. W rosyjską mentalność wpisane jest głęboko nie tylko pragnienie pójścia własną drogą ale również - potęgujący się każdorazowo w okresach smuty - lęk przed społecznym chaosem i rozpadem, obrony przed którymi szuka się w forsownym odbudowywaniu potęgi władzy, utożsamianej nie tyle $\mathrm{z}$ gwarancją, co wręcz $\mathrm{z}$ podstawą porządku społecznego i samego istnienia państwa w nieodmiennie jakoby wrogim Rosji świecie (Mendras, 2007, s. 152-158; Romanczenko, 2005, s. $87 \mathrm{i}$ in., $213 \mathrm{i}$ in., $311 \mathrm{i}$ in.). Jednocześnie jednak, w stopniu, w jakim Putinowska formuła rozwiązywania rosyjskich problemów pozostaje w ramach tradycyjnych sposobów myślenia i działania, których następstwem jest przecież w znacznej mierze rosyjska teraźniejszość, stanowi ona de facto ogniwo procesów ich reprodukcji. Jak dotychczas - czego w odniesieniu do przyszłości Rosji nie należy ani fatalizować, ani lekceważyć - przebiegała ona w ramach algorytmu: autorytaryzm-smuta-autorytaryzm...; nie powinno się oczywiście absolutyzować czy uahistoryczniać identyczności kolejnych powtórzeń, przynoszących przecież każdorazowo, różniące się od poprzednich, formy społeczno-polityczne i ideologiczne.

Pozostawianie w sferze ambicji, zachowań i struktur tradycyjnych, autorytarnych i imperialnych nie jest jednak pozbawione momentu nie tylko antymodernizacyjnego, ale i autodestrukcyjnego - ograniczając, ekstensyfikując, ujednostronniając, wyczerpując i trwoniąc możliwości rozwojowe państwa. Uruchamiane z kolei, charakterystyczne dla okresów rosyjskiej smuty, próby stworzenia nowego, w szczególności wzorowanego na zachodnim, typu porządku społecznego napotykają jednak szybko silne mechanizmy blokujące: dysfunkcjonalność amalgamatu elementów starych i nowych oraz rosnące poczucie groźby całkowitego rozpadu społeczeństwa i państwa popychają ku powrotowi do form tradycyjnych i szukania remedium we wzmacnianiu centralnej władzy. Jej tradycyjnie pojmowana wszechmoc i - demokratyzacyjna, a w pewnym stopniu również modernizacyjna - bezsilność znajdują się zatem zastanawiająco blisko siebie.

Prymat orientacji imperialnej i reaktualizowana idea „silnego państwa" moga prowadzić - w sytuacji wyznaczonej przez spodziewany wzrost potęgi mocarstw niezachodnich, przede wszystkim Chin, które 
stają się potencjalnie alternatywnym w stosunku do Zachodu punktem rosyjskiego odniesienia - do relatywizacji znaczenia kwestii europejskości bądź nieeuropejskości Rosji w tamtejszej kulturze i świadomości, w ogóle, a problemu, pojmowanej na wzór zachodni, demokracji politycznej, w szczególności. Chyba, że w możliwej sytuacji nasilającego się chińskiego czy islamskiego zagrożenia opcja europeizacyjna stanie się, reaktywnie, oparciem i legitymizacją rosyjskiej tożsamości, uruchamiając po raz kolejny złożony zespół ścierających się ze sobą tendencji i kontrtendencji rozwojowych itd. (Broda, 2011, s. 283-286).

Przedstawiona wyżej charakterystyka dotyczy utrwalonego i rozpowszechnionego w Rosji, uświęconego jej wielowiekową tradycją, sposobu konceptualizacji w rzeczywistości społeczno-politycznej, źródeł i uwarunkowań rozpowszechnionego sposobu pojmowania świata i władzy oraz ich instytucjonalnych korelatów i odpowiedników. Pomaga ona - jak sądzę - lepiej rozumieć i pełniej objaśniać skalę wzajemnej odmienności, przeciwstawności i paradoksalności, pojawiających się tam formuł identyfikacyjnych, czasowej i kulturowej odległości, wskazywanych analogii historycznych, oraz wpływu personifikowanych zwykle zmian politycznych na losy kraju, w ogóle, a identyfikacji, diagnoz czy po prostu przesądzeń, dotyczących autokratycznego czy demokratycznego charakteru przemian rosyjskiego systemu politycznego, w szczególności.

Z podobnymi zjawiskami spotykamy się jednak również w wielu zachodnich koncepcjach i diagnozach, odnoszonych do Rosji. Jak można przypuszczać, sprzyjają temu wówczas m.in.: dostrzegany - w sposób ujednostronniony przez dychotomizujące kontrastowanie Rosji z Zachodem - autokratyczny bądź - traktowany jako opis już istniejącej czy stającej się realności - deklarowany przez władzę i konstytucję demokratyczny charakter rosyjskiego systemu politycznego; sugestywność samodzierżawnej lub demokratycznej autoprezentacji politycznej Kremla na zewnątrz; generująca spolaryzowane oceny i identyfikacje dialektyka podobieństwa-niepodobieństwa Zachodu i Popiotrowej Rosji; tendencja do absolutyzowania swobody działania rosyjskiego centrum politycznego i możliwości kreowania przez nie rzeczywistości społecznej kraju; standardy medialno-komercyjnej atrakcyjności spersonifikowanego i udramatyzowanego obrazu świata oraz wpisywanych weń, dokonujących się jakoby właśnie, jednoznacznych i definitywnych przemian; przejawy myślenia życzeniowego, hipostazowania własnych nadziei i obaw; absolutyzowanie albo, przeciwnie, negowanie znaczenia zachodniego odniesienia i wpływu dla tożsamości politycznej i dynamiki rozwojowej państwa rosyjskiego. 
Wspólnym podłożem wielu - nie tylko rosyjskich - prób i towarzyszących im formuł objaśnienia Rosji wydaje się pozostawanie w sferze przedkantowskiej de facto perspektywy teoretycznej, związanej z przeświadczeniem o biernym charakterze, niedostrzegającej nieuchronności każdorazowego współtworzenia poznawanej przedmiotowości przez konstrukcje myślowe, służące jej opisowi i objaśnieniu. (Sprzyjają temu m.in. uwikłanie świadomości społecznej, kultury masowej i przekazu medialnego w archaiczne struktury i sposoby percepcji, przeżywania i konceptualizacji świata oraz, bezwiedne lub świadome, nakładanie się na siebie doświadczenia sacrum i doświadczenia profanum, wiedzy sakralnej, czy quasi-sakralnej, i wiedzy profanicznej (Broda, 2009b, s. 116-124), a w mentalności rosyjskiej, ponadto, silnie obecne w niej: mistyczny realizm, maksymalizm eschatologiczny, ontologizm, binaryzm i, paradoksalnie towarzysząca mu ufność w nieodległą już możliwość finalnego pogodzenie przeciwieństw, ideał ,wiedzy integralnej” itp.) (Broda, 2009c, s. 170-174). W przekonaniu, że poznając prawdziwie odtwarza się jedynie po prostu - i wypowiada - naturę, struktury i właściwości samej rzeczywistości, wpisuje się ją w ramy własnych, przyjętych wcześniej, koncepcji myślowych, przesądzając już z góry o jej zasadniczej naturze, strukturach i właściwościach. Poszukuje się wówczas, wierząc, iż jest to możliwe, jedynej jakoby prawdziwej diagnozy i jednoznacznej wykładni rzeczywistości rosyjskiej, zdolnej wyrazić jej domniemaną istotę, która wcześniej czy później, lecz raczej już niedługo, objawi się w swej czystości i pełni, określając definitywnie oblicze Rosji, w szczególności jej - swoiście rosyjską, samodzierżawną lub prawdziwie czy suwerennie demokratyczną, albo europejską, demokratyczną i obywatelską na wzór zachodni itd. - przyszłość.

Przy podobnym sposobie postrzegania, przeżywania i konceptualizacji świata, prawa, które mają opisywać i wyjaśniać Rosję, przestają być uproszczonym, syntetycznie uporządkowanym zapisem dotychczas zaobserwowanych zależności między różnymi, empirycznie uchwytnymi, zjawiskami, wiedza o których pozwala na formułowanie nieuchronnie hipotetycznych uogólnień i prognoz, a stają się - intencjonalnie - ekskluzywnym rozpoznaniem, opisem i objaśnieniem hipostazowanej czy unadrealnianej domniemanej istoty rosyjskości. Analiza owej ,istoty” umożliwiać ma jakoby wyprowadzanie z niej praw empirycznych, poznanie których umożliwiać ma z kolei dokonywanie - tyleż jednoznacznych, co definitywnych - identyfikacji i diagnoz, dotyczących porządku społecznego i kulturowego w Rosji, czy wręcz „dedukowanie” - „entelechicznie”, „objawieniowo”, 
„samospełnieniowo” itp. pojmowanej - rosyjskiej przyszłości. Gdy z czasem towarzyszący temu, zwykle bezwiednie, zabieg podobnego ,zaklinania” rzeczywistości, pozwalającego, jakby się chciało, przekroczyć granice oddzielające od siebie sfery iluzji i realności, okazuje się nieskuteczny, przychodzi szukać kolejnego ekskluzywnego „klucza” do Rosji. Albo też podjąć wyzwanie, postawione naukowej wiedzy i samoświadomości przez Immanuela Kanta; niepokojąco często aktualne również dziś.

\section{Bibliografia}

Achijezier A., Dawydow A., Szurowskij M., Jakowienko I. (2002), Socykulturnyje osnowanija i smyst bolszewizma, Nowosybirsk.

Afanasjew J. (2009), Kamienna Rosja, martwy lud. Osobna droga Rosji - historyczny bieg w miejscu, „Gazeta Wyborcza”, 24-25 stycznia, s. 12-30.

Billington Dż. (2005), Rossija w poiskach siebia, Moskwa.

Broda M. (1995), Idea szczególnej wolności Rosji, „Obóz. Problemy Narodów Byłego Obozu Komunistycznego", nr 29, s. 23-42.

Broda M. (2002), Russia and the West: The Root of the Problem of Mutual Understanding, „Studies in East European Thought”, s. 10-14, 18-22.

Broda M. (2011), ,Zrozumieć Rosje”? O rosyjskiej zagadce-tajemnicy, Łódź.

Broda M. (2009a), Mentalność, tradycja i bolszewicko-komunistyczne doświadczenie Rosji, Łódź.

Broda M. (2009b), Between 'Sacrum'and 'Profanum': Authority, Knowledge, Democracy, „Limes. Cultural Regionalistics”, Vol. 2, nr 2, s. 116-125.

Broda M. (2009c), Rosyjskie pytania o Rosje jako problem filozoficzny, „Przegląd Filozoficzny - Nowa Seria", nr 19 (69), s. 147-175.

Cirlot J. E. (2000), Stownik symboli, Kraków.

Dobieszewski J. (1986), Przeciwieństwo między Rosja a Europa jako teoria, „Studia Filozoficzne", nr 8 (249), s. 21-39.

Domnikow I. (2003), Mat'-ziemla i Car-gorod. Rossija kak tradicyonnoje obszczestwo, Moskwa.

Eliade M. (1995), Historia wierzeń i idei religijnych, t. 3, Warszawa.

Faryno J. (1995), Buduszczeje, w: Mentalność rosyjska. Stownik, red. A. Lazari, Katowice, s. 12-13.

Iljn I. (2007), Susznost'i swojeobrazije russkoj kultury, Moskwa.

Jakowienko I. (2008), Poznanije Rossii. Cywilizacyonnyj analiz, Moskwa.

Kantor A. (1991), Affiekt i włast' w Rossii, „My i mir. Psichołogiczeskaja gazieta”, nr XI, s. 13-14. 
Kara-Murza A. (1998), Azjopa czyli pop we fraku, „Forum”, nr 50, s. 7.

Kenez P. (2008), Odkłamana historia Zwiazku Radzieckiego, Warszawa.

Klinger J. (1983), O istocie prawosławia, Warszawa.

Kondakow I. (2006), Krizis cywilizacyonnoj idienticznosti w istorii Rossii, w: Isskustwo $w$ kontiekstie cywilizacyonnoj idienticznosti, red. N. Chrienow, t. 1, Moskwa, s. 109-135.

Mendras M. (2007), Powrót do oblężonej twierdzy?, w: Imperium Putina, red. W. Konończuk, Warszawa, s. 145-160.

Meyendorff J. (1984), Teologia bizantyjska. Historia i doktryna, Warszawa.

Pielipienko A., Russkaja sistiema na wiesach istorii (tekst w posiadaniu autora).

Romanczenko Ju. (2005), Ochota na Rossiju. Naszy wragii i ,druzja” w XXI wiekie, Moskwa.

Sakwa R. (2002), Russian Politics and Society, London-New York.

Siergijewa A. (2006), Russkije stierieotipy, powiedienija, tradicyi, mientalnost', Moskwa.

Špidlik T. (2000), Myśl rosyjska. Inna wizja człowieka, Warszawa.

Teichgraber S. I. (1999), Die Dekonstruktion der Socialistichen Mythologie in der Poetik Andrei Platonow, Frankfurt am Main-Berlin-Bern-New York-Paris-Wien.

Timczenko W. (2005), Putin i nowaja Rossija, Moskwa.

Truscott P. (2004), Putin's Progress. A Biography of Russia's enigmatic President, Vladimir Putin, London-Sydney-New York.

\section{Russia - authoritarianism - democracy. Between illusion and reality}

\section{Summary}

The prognostications and forecasts concerning Russia, the nature of the Russian state and its socio-political life are frequently characterized by the extreme or even dichotomous polarization, contradiction and volatility. The reasons and explanation for this can be sought both in the objective (the features of Russian reality) and subjective (the ways of how it is perceived, conceptualized and problematized) factors, which coexist and mutually define one another. 
